\title{
The Effect of Whatsapp Video-Based Education About Childbirth on the Knowledge and Attitudes of Third Trimester Pregnant Women
}

\author{
Eni Sulastri1) Sri Linda2) Triany L. Pelu3) \\ Email : enimuhfi2013@gmail.com
}

\begin{abstract}
Background: One of efforts to reduce maternal and child mortality is childbirth assistance by health workers. In reality in the field the community do not fully trust health workers as childbirth helpers, they prefer traditional birth attendance as childbirth helpers. There is still childbirth assistance by non-health workers (traditional birth attendance), therefore the provision of communication, information and education (CIE) must still be provided in various ways including through social media, one of them is Whatsapp. Health counseling through video media has advantages in terms of providing good visualization to facilitate the process of knowledge absorption

Methods: This study is a Quasy Experimental, it use one-group pretest posttest design. Research took place in the working area of Kalumpang Community Health Center, Ternate city. The study sample included 31 pregnant women who met the inclusion criteria. Data analysis using SPSS statistics version 25 with a paired sample t test

Results: The results of that study there is an increase in knowledge from pretest to posttest after being given educational intervention through whatsapp video about childbirth, with a $p$-value $=0.000$. There was an increase in attitude after being given educational intervention through whatsapp video about childbirth ( $p$-value $=0.000$ ).

Conclusion: The provision of whatsapp video-based education becomes an alternative and successful in providing health information (preparation for childbirth).
\end{abstract}

Keyword : childbirth; video; whatsapp

1,2,3 Department of Midwifery, Poltekkes Kemenkes Ternate, Indonesia Jln. Cempaka Kel. Tanah Tinggi Barat, Ternate, Maluku Utara, Indonesi

Received: July 28, 2021; Revised: September 26, 2021; Accepted: September 28, 2021

Background. One of the important factors in efforts to reduce maternal and child mortality is delivery assistance. Delivery assistance by health workers is a safe delivery service carried out by competent health workers (Marmi, 2016). In reality, the community does not fully trust midwives or health workers as birth attendants, they prefer traditional birth attendants as birth attendants (Nurhidayanti et al., 2018). The selection of birth attendants from non-health workers (traditional birth attendants) usually has an impact that will cause maternal and infant morbidity, as well as childbirth complications, and even death for mothers and their babies. (Alhidayati \& Asmulyanti, 2016).

According to INFID (International NGO Forum on Indonesian Development) data in 2013, the percentage of maternal deaths due to bleeding reached $28 \%$, eclampsia $24 \%$, infection $11 \%$, puerperal complications $8 \%$, abortion $5 \%$, prolonged labor $5 \%$, embolism $3 \%$ and others $11 \%$. The process of giving birth with a traditional birth attendant can contribute to the bleeding rate. This is because traditional birth attendants are less able to recognize pathological conditions during pregnancy and delivery such as anemia in pregnant women, uterine rupture due to pushing the mother's abdomen during delivery, bleeding due to massage the uterus during expulsion of the placenta, and labor not progressing (long labor) because they do not recognize signs of abnormalities in labor (Furi, Lili Tiara., 2014).

The Maternal Mortality Rate (MMR) has decreased from 346 deaths per 100,000 live births in 2010 (2010 Population Census) to 305 deaths per 100,000 births in 2015 (SUPAS 2015) and is targeted to decrease to 183 per 100,000 births in 2024. Infant Mortality Rate 
(IMR) also decreased from 32 deaths per 1,000 $\mathrm{KH}$ in 2012 to 24 deaths per $1,000 \mathrm{KH}$ in 2017 (2017 IDHS) and is targeted to decrease to 16 per $1000 \mathrm{KH}$ in 2024 (Pusat Data dan Informasi, 2020).

Based on the results of Riskesdas 2018, the proportion of birth attendants for women aged $10-54$ years consists of $93.1 \%$ health workers and $6.9 \%$ non-health workers, which includes $28.9 \%$ gynecologist, general $1,2 \%$, midwife $62.7 \%$, nurse $0.3 \%$, traditional healer $6.2 \%$, family/other $0.6 \%$, no helper $0.1 \%$. While the place of delivery consists of Government Hospitals 14.9\%, Private Hospitals 17.8\%, Clinics 4.9\%, Puskesmas/Pustu/Pusling 12.1, Healthcare Practices 29.6, Poskesdes/Polindes $0.0 \%$, Houses 16, 7\%, Others $0.2 \%$ (Kemenkes RI, 2018). This shows that there are still $6.9 \%$ of deliveries that are not assisted by health workers.

Data obtained from the North Maluku Provincial Health Office in January-December 2018 the number of deliveries was 22,921 people. The number of maternal deaths is 49 people, bleeding 20 people, hypertension in pregnancy 2 people, infection 3 people, prolonged labor 6 people.

Based on the results of a preliminary survey with interviews with the KIA/KB Coordinator of the Kalumpang Health Center working area, Ternate City, it was found that in 2018 the target number was 770 people, K1 was 770 people, K4 was 768 people and in 2019 the target number was 805 people but from January to May 2020, the target is 335 people, K1 was 307 people, K4 was 299 people. In 2020 there is still delivery assistance by nonhealth workers or traditional birth attendants in the work area of the Kalumpang Health Center. Therefore, the provision of communication, information and education (CIE) must still be provided in various ways, including through social media.

Based on a survey conducted by the Association of Indonesian Internet Service Providers (APJII), information was obtained that the number of internet users in Indonesia reached 132.7 million people in 2016 and 97.4 percent of internet users in Indonesia use social media. For the communication category, the most popular social media application in the first position is WhatsApp Messenger, which has been downloaded by 1 billion people (Gafi et al., 2020).
The use of video in health education is now starting to be developed along with technological advances. Health education through video media has advantages in terms of providing good visualization so it can facilitate the process of absorbing knowledge. Video is included in audio-visual media because it involves the sense of hearing as well as the sense of sight. This audio-visual media is able to produce better learning outcomes for tasks such as remembering, recognizing recall and connecting facts and concepts (Kholisotin et al., 2019).

Methods. This research is a Quasy Experimental, using a one-group design with pre-test and post-test measurements (one group pretest posttest design). The research site is in the working area of the Kalumpang Health Center, Ternate City. The sample of this study amounted to 31 pregnant women who met the inclusion criteria. Data collection in this study included secondary data collection from medical records at the Kalumpang Health Center, Ternate City and primary data using a checklist and questionnaire in the form of a google form. The data that has been obtained is then analyzed by univariate analysis to describe the characteristics of the respondents. Bivariate analysis to determine the meaning of the provision of WhatsApp video-based education on knowledge and attitudes by using a paired $T$ test after confirming that the data is normally distributed

\section{Result and Discussion.}

Table 1 Characteristics of research subjects

\begin{tabular}{|c|c|c|c|c|}
\hline \multirow[t]{2}{*}{ Characteristics } & \multicolumn{3}{|c|}{ Age (years old) } & \multirow[t]{2}{*}{$P$ value } \\
\hline & $20-25$ & $26-30$ & $31-35$ & \\
\hline Education & & & & 0,000 \\
\hline SMA & 20 & 7 & 0 & \\
\hline S1 & 0 & 0 & 4 & \\
\hline Occupation & & & & 0,031 \\
\hline Work & 0 & 5 & 4 & \\
\hline Not Work & 11 & 7 & 4 & \\
\hline Parity & & & & 0,000 \\
\hline First pregnancy & 20 & 1 & 0 & \\
\hline Second pregnancy & 0 & 6 & 2 & \\
\hline Third pregnancy & 0 & 0 & 2 & \\
\hline
\end{tabular}

Based on table 1, the characteristics of the research subjects/respondents on maternal age with respect to education, occupation and parity. From the data in the characteristics table above using the Chi Square test, it can be seen that there is a relationship between maternal age and education ( $p$ value $=0.000)$, 
occupation $(p$ value $=0.031)$, and parity $(p$ value $=0.000$ )

To ensure that this data will be tested using parametric statistical tests, the researcher first tested the normality of the data using the Kolmogorov-Smirnov test on the results of the knowledge pretest $(p$ value $=0.154)$ and knowledge posttest ( $p$ value $=0.079$ ). It can be concluded that the knowledge pretest and posttest data are normally distributed. Furthermore, for the homogeneity test on the knowledge pretest and posttest data, the $p$ value $=0.866$, which means the data distribution is homogeneous. In the descriptive data obtained the minimum and maximum values, mean, and standard deviation (SD).

Table 2. Differences in knowledge pretest and posttest related to WhatsApp videobased education about childbirth

\begin{tabular}{lcc}
\hline \multicolumn{1}{c}{ Knowledge } & \multicolumn{2}{c}{ Group } \\
& Pretest & Posttest \\
\hline Mean $(\mathrm{X})$ & 14,7742 & 17,1290 \\
Standard Deviation (SD) & 1,74566 & 1,78404 \\
Standard Error Mean & 0,31353 & 0,32042 \\
Range & $12-18$ & $14-20$ \\
\hline p value* & \multicolumn{2}{c}{0,000} \\
\hline
\end{tabular}

As shown in table 2, the paired sample t test illustrates an increase in knowledge after being given an educational intervention through a WhatsApp video about childbirth with a $p$ value of 0.000 , which means that there is an effect of WhatsApp video-based education about childbirth on the knowledge of pregnant women in the third trimester. The provision of educational interventions through WhatsApp videos about childbirth that had been carried out in third trimester pregnant women gave significant results in knowledge which can be seen in the acquisition of values after statistical testing, $\mathrm{p}$ value $<0.05$.

Table 3. Differences in pretest and posttest attitudes related to WhatsApp videobased education about childbirth

\begin{tabular}{lcc}
\hline \multirow{2}{*}{ Attitude } & \multicolumn{2}{c}{ Group } \\
\cline { 2 - 3 } & Pretest & Posttest \\
\hline Mean $(X)$ & 72,5806 & 75,0968 \\
Standard Deviastion (SD) & 3,67672 & 2,56066 \\
Standard Error Mean & 0,66036 & 0,45911 \\
Range & $65-78$ & $70-80$ \\
\hline p value $^{*}$ & \multicolumn{2}{c}{0,000} \\
\hline
\end{tabular}

In table 3, the paired sample t test describes an increase in attitudes after being given an educational intervention through a WhatsApp video about childbirth with a $p$ value of 0.000 which means that there is an effect of WhatsApp video-based education about childbirth on the attitudes of pregnant women in the third trimester.

This increase in knowledge is also related to age, education, occupation, and parity. The age of the respondents in this study is still in the safe range for giving birth, which is 20-35 years and still has a good mindset or grasping power when receiving something, and can think more rationally. This is in line with Bakri's theory which states that women of childbearing age in the age range of 20-35 years have an influence on a person's perception and mindset. Age can affect the condition of the five senses and memory of the respondent. The older they get, the more their patterns of capture power and mindset develop, so that the level of knowledge will increase (Asih, Isti; Kusumawati, 2020).

The education of the respondents is SMA and Bachelor (S1). The higher a person's education, the higher the ability to think than those with lower education and the ease of receiving the information conveyed. With higher education, a person will tend to get information, both from other people and from the mass media (Prawesti et al., 2017). The more information entered, the more knowledge gained about health (preparation for childbirth).

The majority of occupations are housewives and career women. A person's work will affect his life and the amount of information obtained. Working mothers will have a lot of information and experience, while mothers who are only housewives will be limited in the sources of information obtained and tend to be more active working mothers. Women who work have the ability to make decisions to overcome the health problems they face. Therefore, women who act as workers as well as a wife and housewife generally have better health and have a better economic status. However, because the information provided through an application where all pregnant women respondents use the application so that information can be conveyed properly which affects their knowledge.

Maternal parity will affect a person's experience in childbirth. Mothers who have given birth will have more experience and knowledge about the delivery process than mothers who have never given birth. So it requires information for preparation in the birth 
process. A woman's parity can affect the psychological health of pregnant women, especially in the third trimester of pregnancy. Pregnant women with primigravida parity still don't have an idea of what happens during childbirth and are often found feeling afraid because they often listen to stories about what will happen when gestational age is getting closer to the time of delivery with the image of a scary delivery process, while pregnant women with multigravida parity already have an overview of pregnancy and childbirth from previous pregnancies. So that when pregnant they tend to be more mentally and psychologically prepared (Rinata \& Andayani, 2018). In this study, there was an increase in knowledge after being given education about childbirth through WhatsApp videos. This is because the dissemination of information is something that must be considered so that information is maximized and its goals can be achieved and can change a person's attitude or behavior for the better. The limited communication space makes the dissemination of information ineffective and miss communication often occurs. However, today many communication technologies are designed to facilitate the dissemination of information. For the communication category, the most popular social media application in the first position is whatsapp messenger (Kholisotin et al., 2019). The WhatsApp application is one of the tools to communicate that is used by all groups that can facilitate the delivery of messages or information effectively and efficiently in a timely manner, this application also serves to increase the attractiveness of the information to be conveyed so as to increase their knowledge (Narti, 2018).

The intervention in this study was the use of preparatory videos for delivery. The use of video as a means of health education is now starting to be developed along with current technological advances. Health counseling through video media has advantages in terms of providing good visualization so as to facilitate the process of absorbing knowledge. Video is included in audio-visual media because it involves the sense of hearing as well as the sense of sight. This audio-visual media is able to produce better learning outcomes such as remembering, recognizing, recalling and connecting facts and concepts (Sari, 2019). Video can depict an object moving in tandem with natural sounds or appropriate sounds. The video in this study provides information about pregnant women so that they avoid old habits (cultural factors) to choose to check with traditional birth attendants rather than check at health facilities that have adequate equipment during the pregnancy to delivery process, in addition there are videos of the delivery process, preparation for delivery , and complications in pregnancy and childbirth.

This study focuses on the use of social media whatsapp, because whatsapp is the most popular social media by the community. Whatsapp is a social media application designed to make it easier for users to communicate through a variety of available features, including chat groups, whatsapp on the web and desktop, whatsapp voice and video calls, end-to-end encryption, photo and video sending, voice messages, and documents. Video is the media most often used by health promoters as a medium that facilitates the development of cognitive aspects to individual skills and the scope of the community (Kholisotin et al., 2019). Knowledge is the result of knowing, and this occurs after people have sensed a certain object. Sensing occurs through the five human senses, namely the senses of sight, hearing, smell, taste and touch. Knowledge is a very important domain for the formation of one's actions. Most of a person's knowledge is obtained through the sense of hearing (ears) and the sense of sight (eyes) (Notoatmodjo, 2012).

The provision of educational interventions through whatsapp videos about childbirth that had been carried out in third trimester pregnant women gave significant results in attitudes that could be seen in the score after being tested statistically, the $p$ value $<0.05$, which means the hypothesis was tested and accepted. To ensure that this data will be tested using parametric statistical tests, the researcher first tested the normality of the data using the Kolmogorov-Smirnov test on the results of the attitude pretest ( $p$ value $=0.200$ ) and the attitude posttest ( $p$ value $=0.200$ ). It can be concluded that the knowledge pretest and posttest data are normally distributed. Furthermore, to test the homogeneity of the knowledge pretest and posttest data obtained $p$ value $=0.075$, which means that the data distribution is homogeneous. In the descriptive data obtained the minimum and maximum values, mean, and standard deviation (SD). 
In this study, there was an increase in attitudes before and after being given educational interventions about childbirth through WhatsApp videos. Attitude is a person's feelings or views accompanied by a tendency to act on an object or stimulus. Factors that influence attitudes are personal experience, other people who are considered important, mass media, and education.

Mass media is one of the factors in achieving information, mass media carry suggestive messages that can influence individual opinions. If the suggestive messages conveyed are strong enough, they will provide an effective basis for assessing something to form a certain attitude. The mass media in this study is the provision of information via video via mobile phones using the WhatsApp application. The more mature a person's age will affect his experience, both in gaining knowledge and determining attitudes, information. Based on experience, a person can exchange ideas or share, so as to increase knowledge which will ultimately affect attitudes.

Conclusion and Suggestions. There is an effect of WhatsApp video-based education about childbirth on the knowledge and attitudes of third trimester pregnant women. The provision of video-based education through WhatsApp is an alternative and successful in providing health information (preparation for childbirth)

Acknowledgements The author would like to thank the Director of Poltekkes Kemenkes Ternate, Head of the Center for Research and Community ServicePoltekkes Kemenkes Ternate, Head of the Department of Midwifery and all parties from Poltekkes Kemenkes Ternate who have helped and provided motivation and support.

\section{References}

Alhidayati, \& Asmuliyanti. (2016). Persalinan Di Wilayah Kerja Puskesmas Tembilahan Hulu Tahun 2016 (Delivery in the Working Area of Tembilahan Hulu Health Center 2016). Jurnal Kesehatan Reproduksi (Journal of Reproductive Health), 3(3), 155-162.

Asih, Isti; Kusumawati, Y. (2020). Hubungan Usia, Pendidikan dan Paritas lbu dengan Pengetahuan Kesehatan Mental Ibu Hamil di Kota Surakarta. In Universitas Muhammadiyah Surakarta. Universitas
Muhammadiyah Surakarta.

Furi, Lili Tiara., dan H. M. (2014). Faktor Yang Mempengaruhi lbu Bersalin Pada Dukun Bayi Dengan Pendekatan Who Di Desa Brongkal Kecamatan Pagelaran Kabupaten Malang. Jurnal Promkes, 2(1), 77-88. http://journal.unair.ac.id/downloadfullpapers-jupromkes9aa444b4aafull.pdf

Gafi, A. Al, Hidayat, W., \& Tarigan, F. L. (2020). Pengaruh Penggunaan Media Sosial Whatsapp Dan Booklet Terhadap Pengetahuan Dan Sikap Siswa Tentang Rokok Di Sma Negeri 13 Medan. Jurnal Muara Sains, Teknologi, Kedokteran Dan IImu Kesehatan, 3(2), 281. https://doi.org/10.24912/jmstkik.v3i2.5656

Kemenkes RI. (2018). Laporan Nasional Riset Kesehatan Dasar. Kementerian Kesehatan RI, 1-582.

Kholisotin, K., Agustin, Y. D., \& Prasetyo, A. D. (2019). Pengaruh Penyuluhan Berbasis Video Whatsapp tentang Persalinan Terhadap Pengetahuan dan Sikap lbu Hamil Trimester III di Puskesmas Klabang Kabupaten Bondowoso. Jurnal Surya, 11(02), $1-9$. https://doi.org/10.38040/js.v11i02.32

Marmi. (2016). Intranatal Care (Asuhan Kebidanan Pada Persalinan). In Pustaka Pelajar: Yogyakarta: Vol. ISBN:978-6.

Narti, S. (2018). Pemanfaatan "Whatapp" sebagai Media Komunikasi Dosen dengan Mahasiswa Bimbingan Skripsi (Studi Analisis Deskriptif Pada Mahasiswa IImu Komunikasi Bimbingan Skripsi Universitas Dehasen Bengkulu Tahun 2016 ). Profesional: Jurnal Komunikasi Dan Administrasi Publik, 4(1). https://doi.org/10.37676/professional.v4i1. 448

Notoatmodjo, S. (2012). Promosi Kesehatan dan Perilaku Kesehatan. edisi revisi. In Jakarta: Rineka Cipta.

Nurhidayanti, S., Margawati, A., \& Kartasurya, M. I. (2018). Kepercayaan Masyarakat terhadap Penolong Persalinan di Wilayah Halmahera Utara. Jurnal Promosi Kesehatan Indonesia, 13(1), 46. https://doi.org/10.14710/jpki.13.1.46-60

Prawesti, I., Haryanti, F., \& Lusmilasari, L. (2017). Pengaruh Edukasi Kesehatan dengan Media Video dan Brosur terhadap Literasi Kesehatan Ibu di Wilayah Kerja Pukesmas Saptosari Kabupaten Gunungkidul Yogyakarta. 
http://etd.repository.ugm.ac.id/penelitian/d etail/129000

Pusat Data dan Informasi, K. R. (2020). Profil Kesehatan Indonesia Tahun 2019. In Kementerian Kesehatan Republik Indonesia. www.journal.uta45jakarta.ac.id

Rinata, E., \& Andayani, G. A. (2018). Karakteristik ibu (usia, paritas, pendidikan) dan dukungan keluarga dengan kecemasan ibu hamil trimester III. Medisains, 16(1), 14. https://doi.org/10.30595/medisains.v16i1. 2063

Sari, W. (2019). Pengaruh media video terhadap pengetahuan tentang deteksi dini kanker payudara pada remaja putri di SMAN 1 Sanden Bantul tahun 2019. 53. http://poltekkesjogja.ac.id/ 